\title{
43. LOWER CRETACEOUS AND JURASSIC OSTRACODS FROM DSDP LEG 27- A PRELIMINARY ACCOUNT
}

\author{
Henri J. Oertli, Société Nationale des Pétroles d'Aquitaine, \\ Centre de Recherches, Pau, France
}

\begin{abstract}
The study of Albian sediments at Sites 259, 260, and 263 (22 samples) yielded 16 species of ostracods, of unknown specific and partially generic level. Seven other species, each with only one specimen, could be observed in a sample at Site 261, Core 33 (Oxfordian). The Cretaceous associations are widely dominated by Arculicythere? sp. A. Other frequent forms are Bairdiids and Indet. sp. A, a species possibly belonging to Robsoniella.

These associations suggest deposition in an environment deeper than shelf (except the Oxfordian sample at Site 261, which might be nearshore).

Many specimens are strongly corroded, but the associations seem to be mainly in situ (cohabitation of adults and numerous larval stages).
\end{abstract}

\section{INTRODUCTION}

The ostracods described here were provided by $\mathrm{H}$. Bolli, a participant on Leg 27, who sent me a series of slides with ostracods taken from Albian samples at Sites 259 (13 samples from five cores), 260 ( 5 samples from three cores), and 263 (4 samples from three cores), as well as one slide (with seven specimens) from the upper Jurassic at Site 261 (for a detailed list, see Figure 1).

The comparison of the associations with faunas of similar age yielded no positive results on a specific level. The reason may be an age difference (published data on Cretaceous deposits from Australia', India, and South Africa concern either essentially the lowest or the upper Cretaceous), or, most probably, a facies difference. The published data deal essentially with shallow water or shelf faunas, whereas the Albian associations of Leg 27 seem to be characteristic of off-shelf sediments. For this reason, I had to follow the given age indications (from preliminary reports of the Leg 27 staff) without being able to discuss the chronostratigraphy of the deposits.

The preservation of most specimens is rather poor, and only a few species ( 5 out of 22 ) have more than five specimens. Figures of all observed species are included, since forms that are questionable at present because of lack of references, poor preservation, or few specimens may be helpful in the future by comparison with other material.

\section{SITES AND SPECIES}

Figure I shows distinctly that, in general, each of the four sites has its own assemblage. This is not particularly surprising for the Oxfordian core of Site 261,

\footnotetext{
'I gratefully acknowledge assistance of John Neale, Hull,England, who sent me still unpublished plates on the Chapman (1917) type specimens from Australia and other species from the Gingin Chalk.
}

but it is very surprising in the case of the presumed Albian material from the three other sites. Sites 259 and 260 have but one common species (and another questionable); Sites 260 and 263 as well as 259 and 263 only have one questionable species in common. It is true that Site 263 has a paucity of individuals and may therefore not be significant. The assemblages at Sites 259 and 260 are markedly different: the former is dominated by the well-ornamented Arculicythere ? sp. A, which is sometimes the unique constituent of a sample (generally represented by instars); the latter has no strongly ornamented species and contains as its essential element Indet. sp A. From a total of 228 specimens belonging to 23 species, $63 \%$ are representative of Arculicythere? sp. A, followed by Bairdia? sp. A and Indet. sp. A ( $9 \%$ each) and Bairdia sp. B (4\%).

\section{Site 259}

Arculicythere? sp. A (Plates 4 and 5), though the most numerous and best preserved species, is presented in open nomenclature ${ }^{2}$. In its general aspect, this species fits quite well into the generic group, but I could not be sure about the median hinge element which appears to be crenulated (see Plate 5, Figure 2, a right valve). Smooth portions in several left valves (Plate 5, Figure 7) may be due to corrosion. No specimen is sufficiently well preserved to show if the anterior part of the median hinge is really of a progonocytherid type (Grekoff,1963).

Bairdia sp. A (Plate 1) is very typical because of its angular dorsal outline and the posterior extremity which

\footnotetext{
${ }^{2}$ acknowledge the help of R. V. Dingle in comparing this species with his Arculicythere tumida from South Africa (Dingle, 1971). A. tumida (Barremian or slightly younger; Agulhas Bank, Southeast Cape Town) is differentiated by a distinct eye spot, a subdivided median ridge and a punctate (not reticulate) surface.
} 


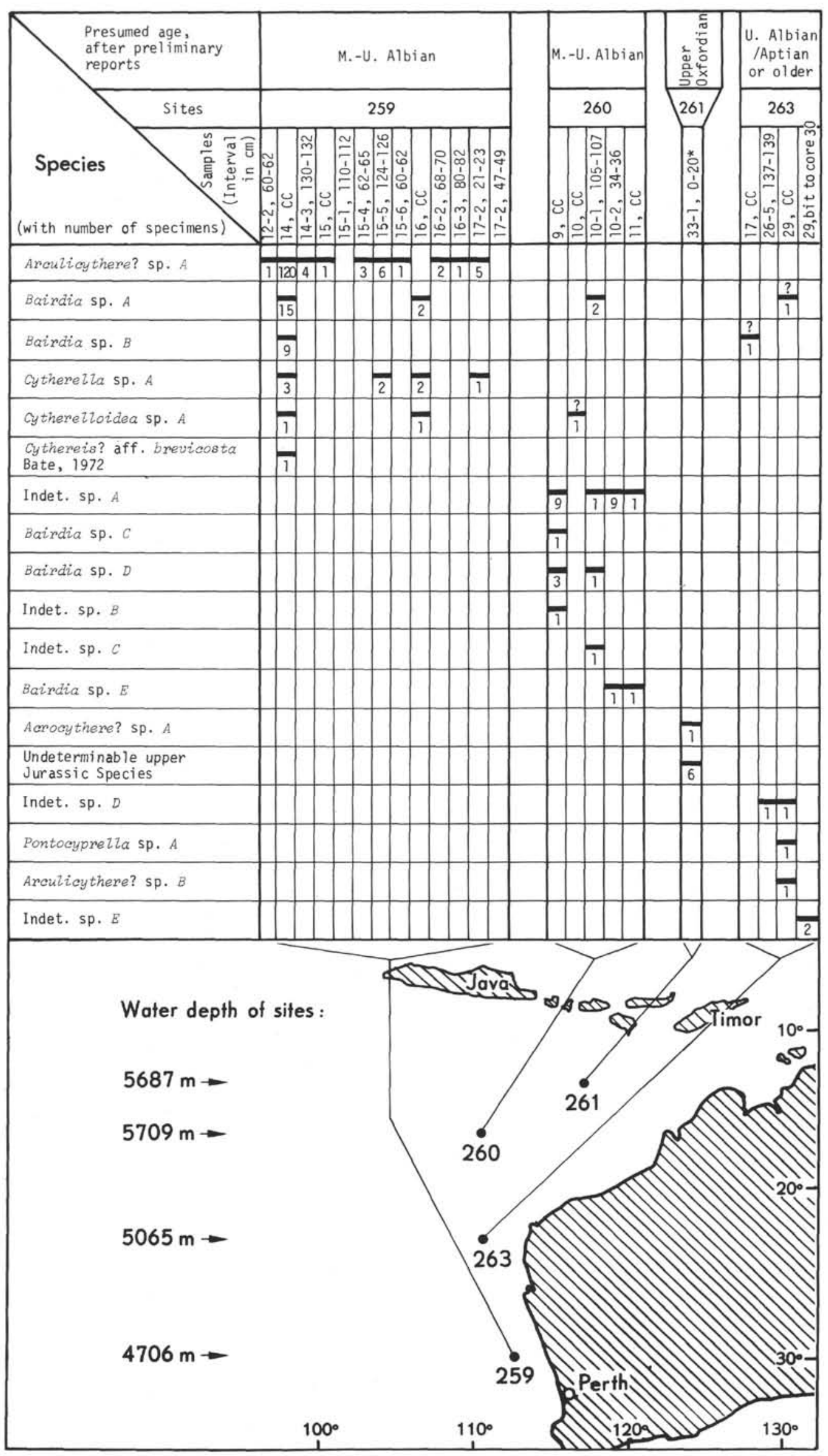

Figure 1. Location, distribution, and frequency of pre-Tertiary ostracods is some samples of DSDP Leg 27. 
forms a right angle and sometimes a slight protrusion. It shows some resemblance to Bairdia sp. = ostracod G 1 of Gowda, 1966 (upper Cenomanian of the Trichinopoly area, India), but the latter has its anterior extremity higher up.

Bairdia sp. B has a vague affinity with Bairdia sp. 1 Gründel, 1966 (Hauterivian, Germany), but is more densely punctate. Bairdia cretacea Veen, 1934 (uppermost Cretaceous, Northern Europe), has a similar punctation, but a higher anterior part.

There is nothing special about the other Bairdiid (Plate 3) and two Cytherellids (Plate 1) found at the same site.

The only species comparable to known types is Cythereis ? aff. brevicosta Bate, 1972, which is represented by a single and poorly preserved specimen (possibly it is not in situ). It shows also a slight resemblance to Isocythereis sealensis Dingle, 1971, but is larger and has no distinct median ridge.

\section{Site 260}

The species of this site are essentially Bairdiids, the most abundant being Indet. sp. A (60\% of all individuals of this site) (Plate 6). This very peculiar species is reminiscent of Robsoniella obovata (Kuznetsova, 1957) (upper Aptian, Southern Russia) as much in its outline as in the hinge, but it has a slightly larger hinge in the left valve; the right valve is not so high. Unfortunately, no specimen revealed muscle scar prints or marginal pore canals, but some specimens showed a large vestibulum. As Kuznetsova has already observed, the hinge calls to mind Ogmoconcha, but it differs by its positive median hinge element. As there was not enough time to obtain type material concerning Robsoniella and establish the possible identity, the generic attribution was left in open nomenclature.

Bairdia sp. D (Plate 3, Figures 7-9) has some resemblance to Bairdia sp. A, but is differentiated by its steep posterodorsal slope. It is also more globular.

Indet. sp. B (Plate 7, Figure 1) brings to mind Cytherura? saratogana Israelski, 1929 (Maestrichtian, Arkansas), but it seems that the longitudinal ridges of the latter do not converge towards the middle of the anterior margin.

Indet. sp. C (Plate 7, Figure 2) may be a larval stage of an unknown species (Protocytherid ?); it is unlikely to be an Acrocythere.

\section{Site 261}

The only sample from this site (Core 33 above the basalt basement, dated upper Oxfordian by nannofossils) contained seven specimens of micro-ostracods (Plate 7, Figures 6-12), each one obviously belonging to a different species. Their preservation is poor, and apart from what might be an Acrocythere. I have left them in open nomenclature. One might be tempted to recognize a "Bythocypris" or "Pontocyprella," a "Schuleridea," a "Metacytheropteron", but this remains rather hypothetical.

\section{Site 263}

The four samples at this site are sparse and poorly preserved. Two species of Bairdia may belong to sp. A and sp. B found at Site 259. Arculicythere ? sp. B resembles (as does sp. A) A. tumida Dingle,1971, but it is differentiated by its much larger and more flattened anterior part. The three other forms, Pontocyprella sp. A, Indet. sp. D and E, have not been detected elsewhere and seem of little help and interest.

\section{Paleoecology}

All samples that are relatively rich in individuals contain large (adult) as well as very tiny specimens (larval stages or micro-ostracods). This may be interpreted as a sign of the absence of currents, i.e., most specimens seem to be autochthonous.

Most specimens have a more or less corroded surface (see Plate 2 in particular). The outer protective (organic) layer is mainly removed (Oertli, in press), thus implying an oxidizing environment.

In some cases, recrystallization appears to have taken place after burial-see the partial inclusion of nannofossils in crystal (Plate 1, Figure 10 and Plate 5, Figure 3). Perhaps in this case the coccolith acted as a nucleus for the crystal. In some specimens of Arculicythere ? sp. A, the opening of lateral pore canals visibly favored the formation of crystals (Plate 5, Figures 3, 9, 10).

The depth of deposition seems to have been deeper than a shelf environment in the case of Sites 259 and 260 as indicated by the dominance of smooth forms, mainly Bairdiids and Cytherella, as well as of an eyeless ornamented species. Except for one specimen, the $C y t h e r e i s$ group is completely absent-a group everywhere significant in nearshore or shelf deposits of middle Cretaceous age.

Though the few specimens of the lowermost core (upper Oxfordian) of Site 261 are of uncertain taxonomic position, their general shape and character suggest a shallow-water environment.

Only a few noncharacteristic specimens were recovered from Site 263. These appear to be ecologically similar to those at Sites 259 and 260.

\section{REFERENCES}

Bate, R. H., 1972. Upper Cretaceous ostracoda from the Carnarvon Basin, Western Australia: Spec. Paper Palaeontol., v. 10.

Bate, R. H. and Bayliss, D. D., 1971. An outline account of the Cretaceous and Tertiary foraminifera and of the Cretaceous ostracods of Tanzania: African Micropaleontol. Coll. Proc, 3rd, p. 113.

Chapman, F., 1917. Monograph of the foraminifera and ostracoda of the Gingin Chalk: Geol. Surv. West. Australia Bull., v. 72 , p. 1 .

Dingle, R. V., 1971. Some Cretaceous ostracodal assemblages from the Agulhas Bank (South African Continental Margin): Roy. Soc. S. Africa Trans., v. 39, p. 393.

Gowda, S. S., 1966. Some ostracods from the Trichinopoly Cretaceous of South India: Geol. Soc. India Bull., v. 3, p. 42.

Grekoff, N., 1963. Contribution à l'étude des Ostracodes du Mésozoïque moyen (Bathonien-Valanginien) du Bassin de Majunga, Madagascar: Rev. Inst. Francais Pétrol., v. 18, p. 1709.

Gründel, J., 1966. Taxionomische, biostratigraphische und variations-statistische Untersuchungen an den Ostracoden der Unterkreide in Deutschland: Freib. Forsch., v. 200. 


\section{H. J. OERTLI}

Israelski, M. C., 1929. Upper Cretaceous ostracoda of Arkansas: Arkansas Geol. Surv. Bull., v. 2.

Kuznetsova, Z. V. 1957. Ostracoda. In Material of paleontology: v. 12 , p. 87.

1961. Cretaceous ostracodes from NE Azerbaidjan and their stratigraphical significance: Baku.

Mandelstam, M. I., et al., 1957. Ostracoda. In Material of paleontology: v. 12 , p. 87.
Oertli, H. J., in press. SEM observations on the ostracode shell ultrastructure with regard to its preservation: Report on Symposium on Biology and Paleobiology of Ostracoda, Newark, Delaware, August 1972.

Veen, J. E., van., 1934. Die Cypridae und Bairdiidae der Maastrichter Tuffkreide und des Cunrader Korallenkalkes von Süd-Limburg: Natuurhist. Maandbl., v. 23, p. 88. 


\section{PLATE $1^{3}$}

Magnifications: all $\times 90$ except Figure 9: $\times 1800$ and Figure 10: $\times 4000$. Localities: all Sample 259-14, CC except Figure 4:

Sample 259-16, CC, and Figure 6: Sample 260-10-1, 105-107 cm

Figures 1, 2 Cytherella sp. A.

1. Right valve, ref. $36 / 6 / 1$.

2. Left valve, ref. $35 / 5 / 1$.

Figures 3,4 Cytherelloidea $\mathrm{sp}$. A.

3. Left valve, ref. $35 / 5 / 2$.

4. Right valve, ref. $35 / 5 / 3$.

Figures 5-10 Bairdia sp. A.

5. Left valve, ref. $37 / 1 / 1$.

6. Right valve, ref. $35 / 4 / 4$

7. Right valve, ref. $37 / 1 / 2$.

8. Left valve (juvenile? 7 , ref. $35 / 4 / 1$ ).

9. Detail of Figure 8: central part of lateral surface, showing loose arrangement of crystallites (see also Plate 2).

10. Sediment in the interior of a right valve, showing a coccolith captive of a crystal; ref. $27 / 1 / 3$.

\footnotetext{
${ }^{3}$ All pictures by the author, except Figures 11 and 12 of Plate 5, 1 owe to my colleague, $\mathrm{F}$. Deres.
} 


\section{PLATE 1}
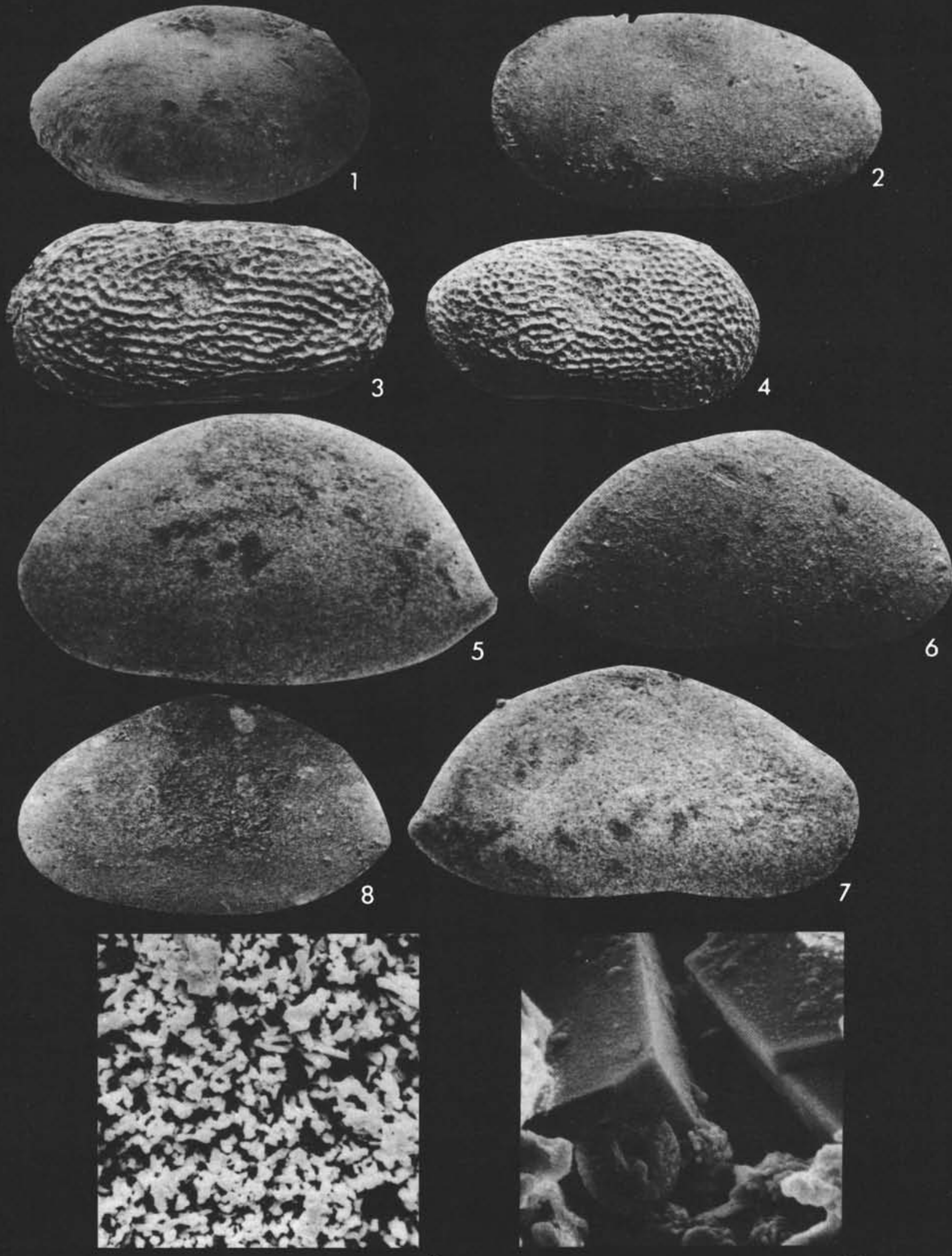


\section{PLATE 2}

Magnifications: Figure 1: $\times 90$; Figure $2: \times 180$;

Figures 3, 4, 7: $\times 4000$; Figures 5, 6: $\times 1800$. Localities: all Sample 259-14, CC.

(all figures are of the same right valve; ref. 35/4/3)

Figures 1-7 Bairdia sp. A. Detail of surface structure. 1,2. Right valve and its anterior part.

3. Crystallites of the median layer; note the very loose arrangement that facilitates destruction. 4-7. Different views of the contact of the middle layer with the "chitinous" external layer (cf. Oertli, in press). 


\section{PLATE 2}

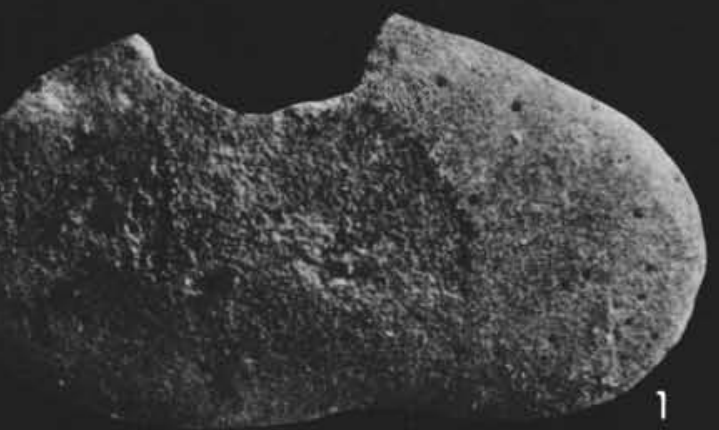

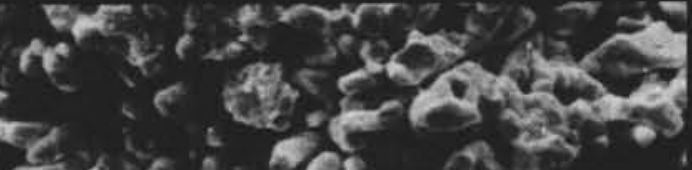

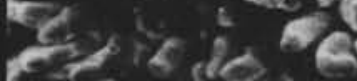

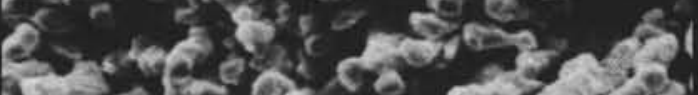

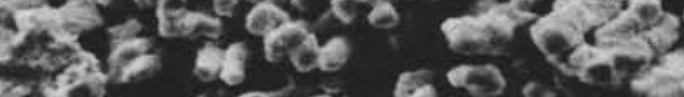

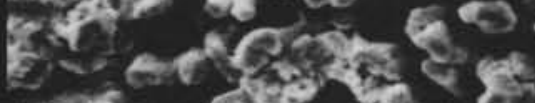

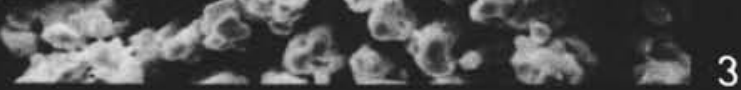
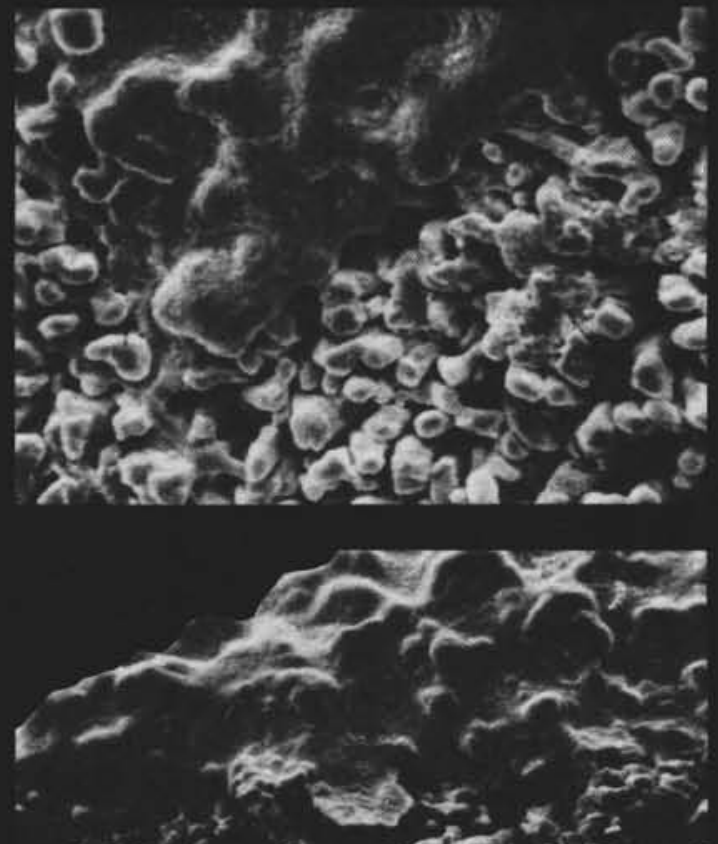

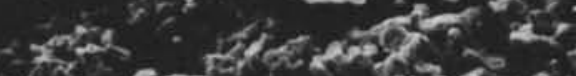

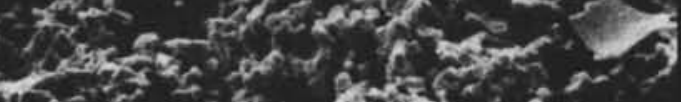

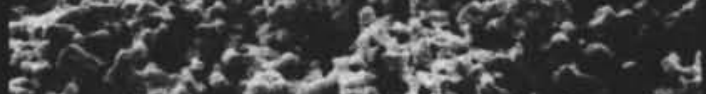
द.

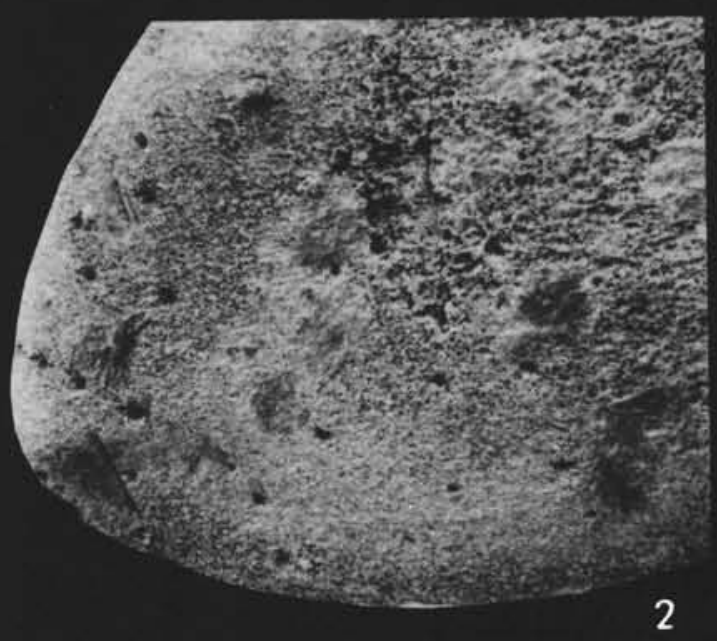

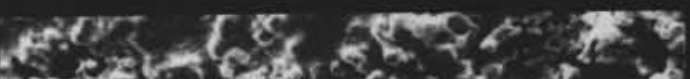

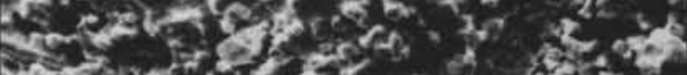

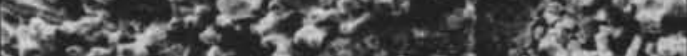
Cos 5 .

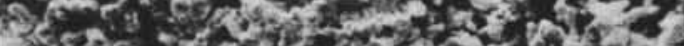

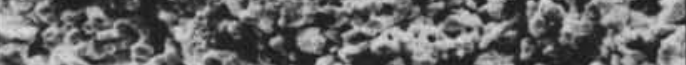

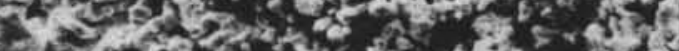

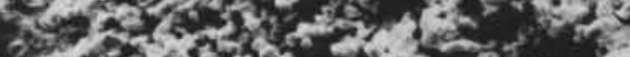

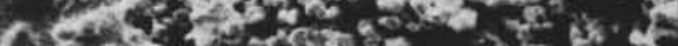

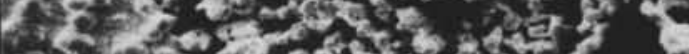

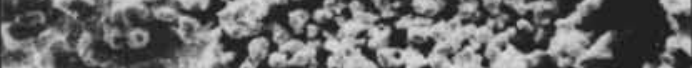

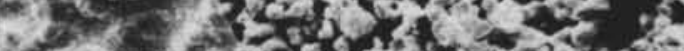

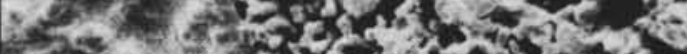

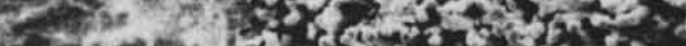

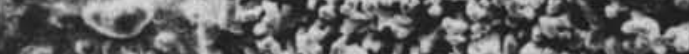

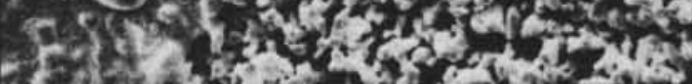

\section{6}

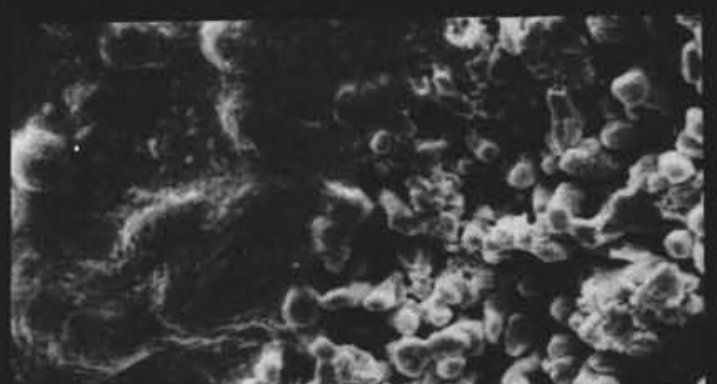

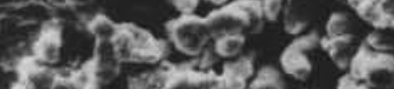

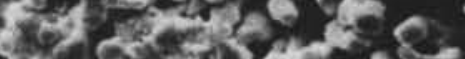
the

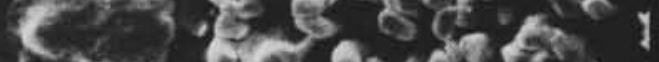

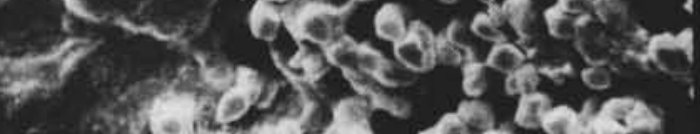

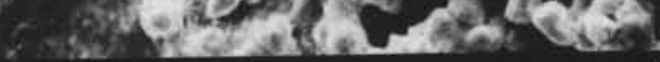




\section{PLATE 3}

Magnifications: all $\times 65$.

Localities: Figure 1-5, 10: Sample 259-14, CC;

Figure 6-9: Sample 260-9, CC; Figure 11: Sample 263-29, CC.

Figures 1-5 Bairdia sp. B.

1. Left valve, ref. $37 / 5 / 1$.

2. Right valve (juvenile), ref. $37 / 5 / 2$.

3. Left valve, ref. $35 / 6 / 3$.

4. Right valve, ref. $35 / 6 / 2$.

5. Right valve, ref. $35 / 6 / 1$.

Figure $6 \quad$ Bairdia sp. C. Fragmentary left valve, ref. 35/7/3.

Figures 7-9 Bairdia sp. D.

7. Partially separated carapace, ref. $35 / 8 / 1$.

8. Left valve, ref. $35 / 8 / 3$.

9. Left valve, ref. $37 / 7 / 2$.

Figure $10 \quad$ Bairdia sp. E. Right valve, ref. 37/3/1.

Figure $11 \quad$ Pontocyprella sp. A. Carapace, ref. 36/3/2. 


\section{PLATE 3}
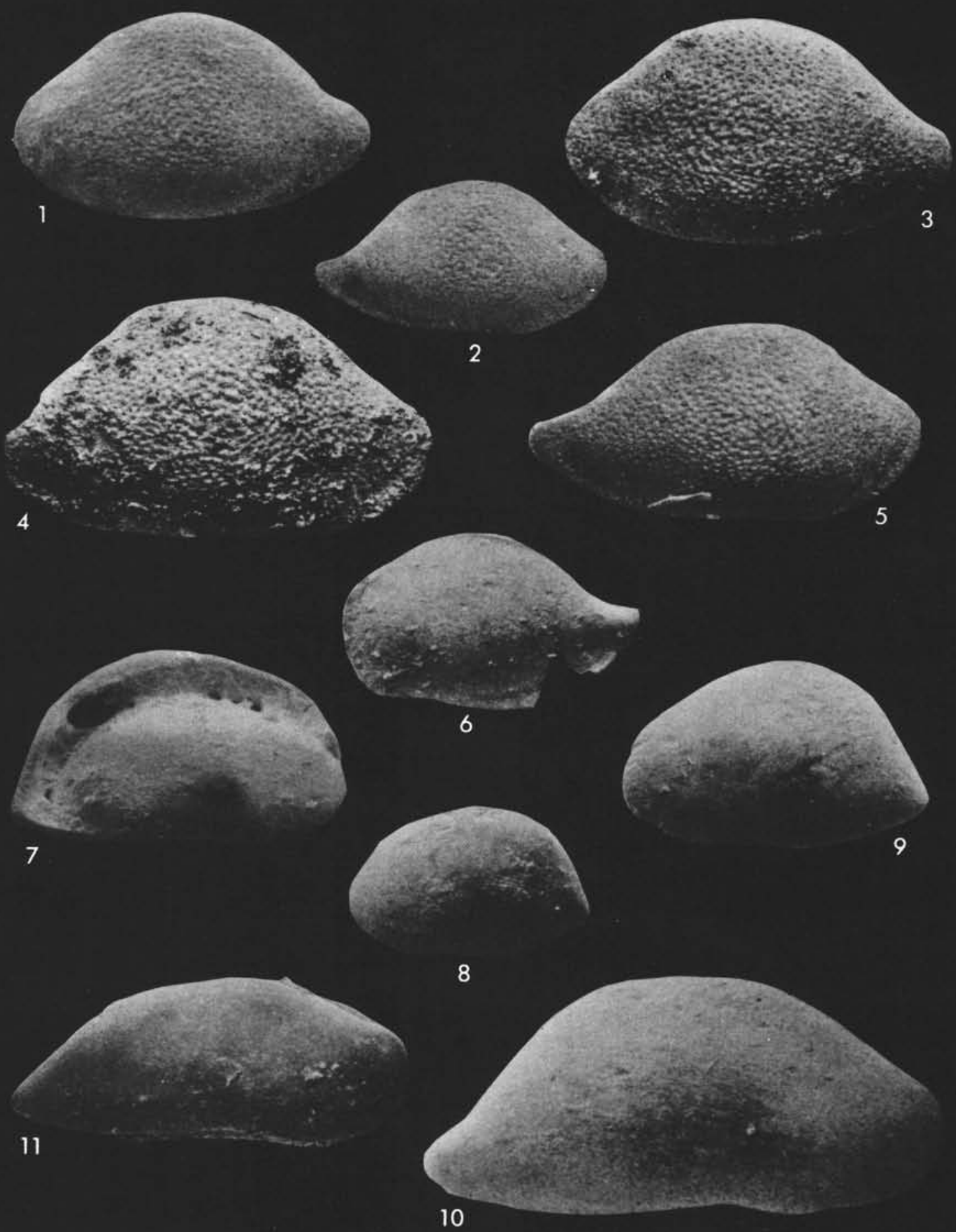


\section{PLATE 4}

Magnifications: all $\times 90$.

Localities: Figure 1-11, 13: Sample 259-14, CC;

Figure 12: Sample 263-29, CC.

Figures 1-11 Arculicythere?sp. A.

1-6: instars.

1. Left valve, ref. 35/1/1.

2. Left valve, ref. $35 / 1 / 2$.

3. Left valve, ref. $35 / 1 / 3$.

4. Left valve, ref. $35 / 1 / 4$.

5. Left valve, ref. $35 / 1 / 5$.

6. Left valve, ref. $35 / 1 / 6$.

7. Right valve $ᄋ$, ref. $35 / 2 / 2$.

8. Left valve of, ref. $35 / 2 / 4$.

9. Carapace o ref. 35/3/1.

10. Carapace o dorsal view, ref. $35 / 2 / 5$.

11. Right valve $\delta$ ref. $35 / 2 / 3$.

Figure 12 Arculicythere ? sp. B. Carapace, ref. 36/3/1.

Figure 13 Cythereis ? aff. brevicosta Bate, 1972. Right valve, ref. $37 / 2 / 3$. 


\section{PLATE 4}

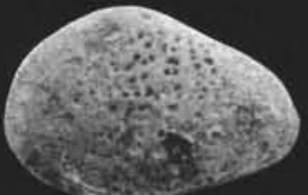

1
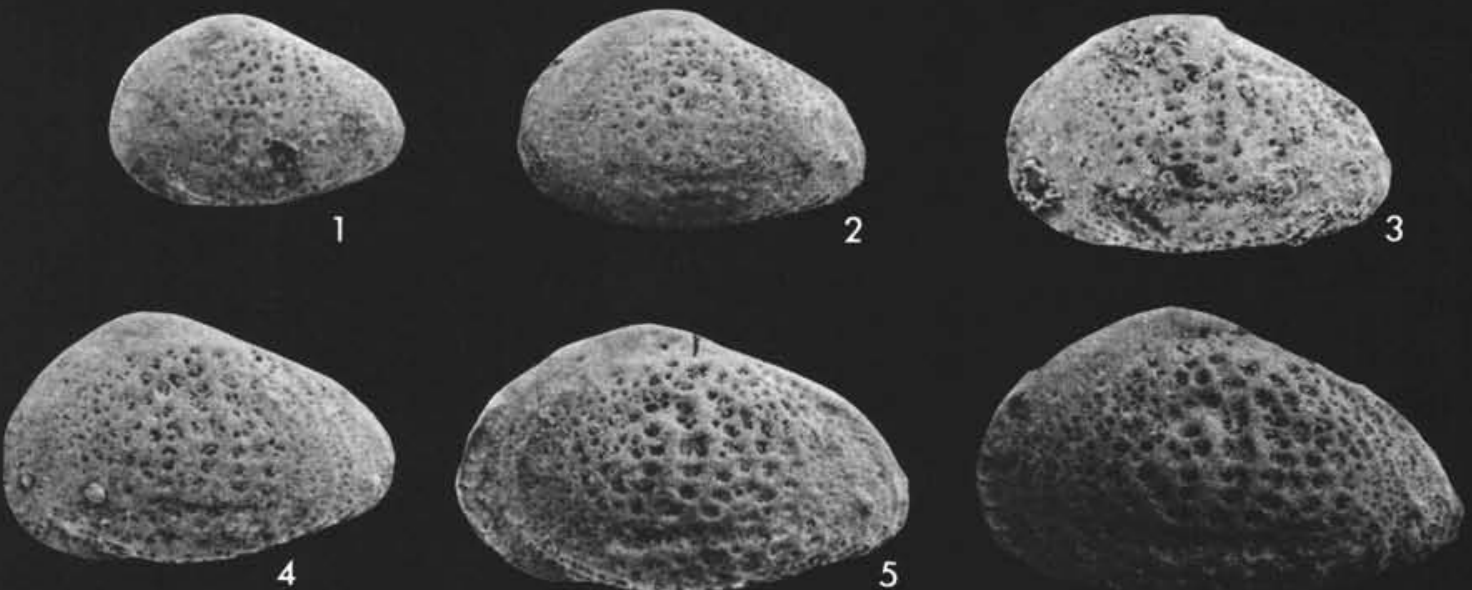

6
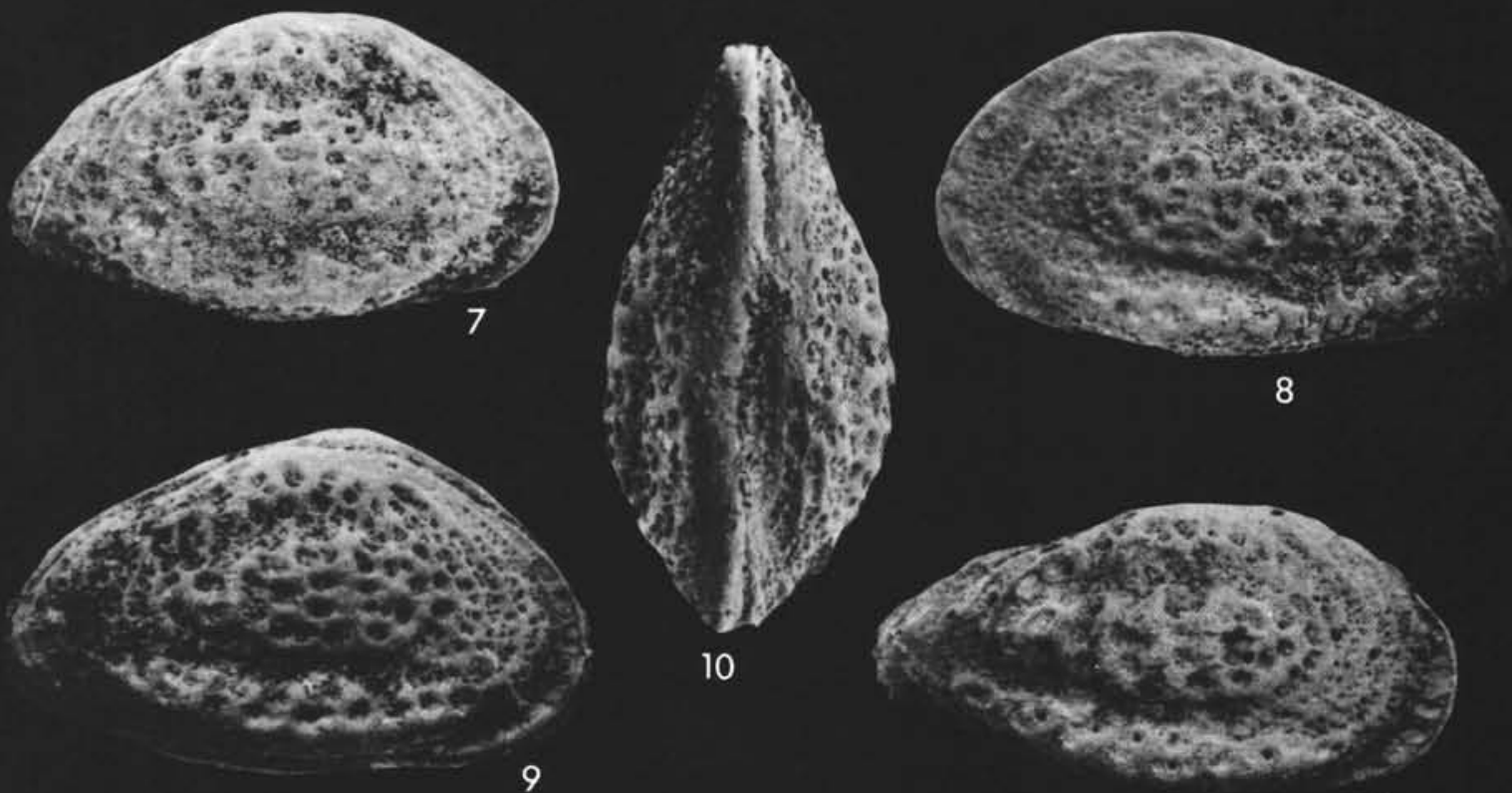

\section{8}

10

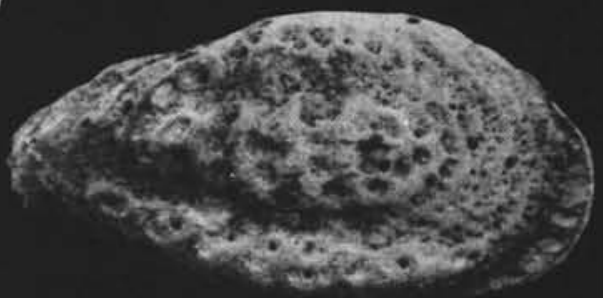

11

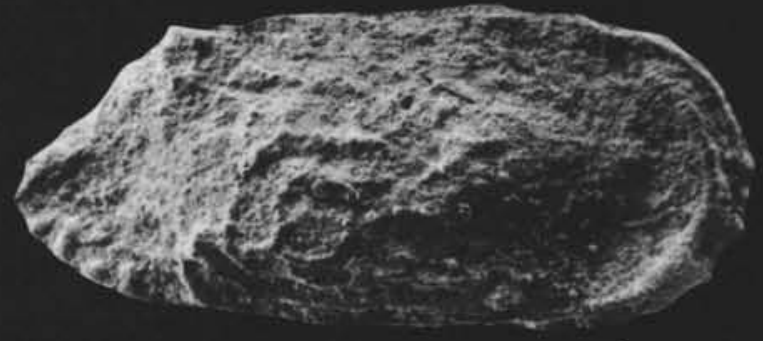

12

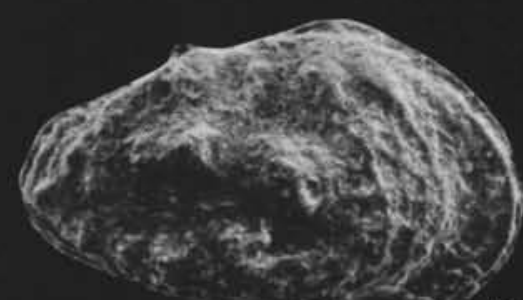

13 


\section{PLATE 5}

Magnifications: Figures 1, 4, 6, 7: $\times 90$;

Figure 2: $\times 180$; Figure 3: $\times 800$; Figures 5, 8: $\times 450$;

Figures 9, 10: $\times 1800$; Figures 11, 12: $\times 125$.

Localities: all Sample 259-14, CC.

Figures 1-12 Arculicythere? sp. A. Interior views.

1. Right valve, ref. $37 / 2 / 2$.

2. Same specimen, detail of hinge line.

3. Same specimen, crystallization on lateral pore canal. with partial inclusion of a coccolith.

4. Right valve, ref. 36/5/1.

5. Same specimen, detail of muscle scars.

6. Left valve, ref. $35 / 3 / 2$.

7. Left valve, ref. $36 / 5 / 2$.

8. Same specimen, detail of anterior hinge element.

9, 10. Same specimen, crystallization on lateral pore canal opening.

11, 12. Anterior marginal zone of left and right valve in transmitted light. 
PLATE 5
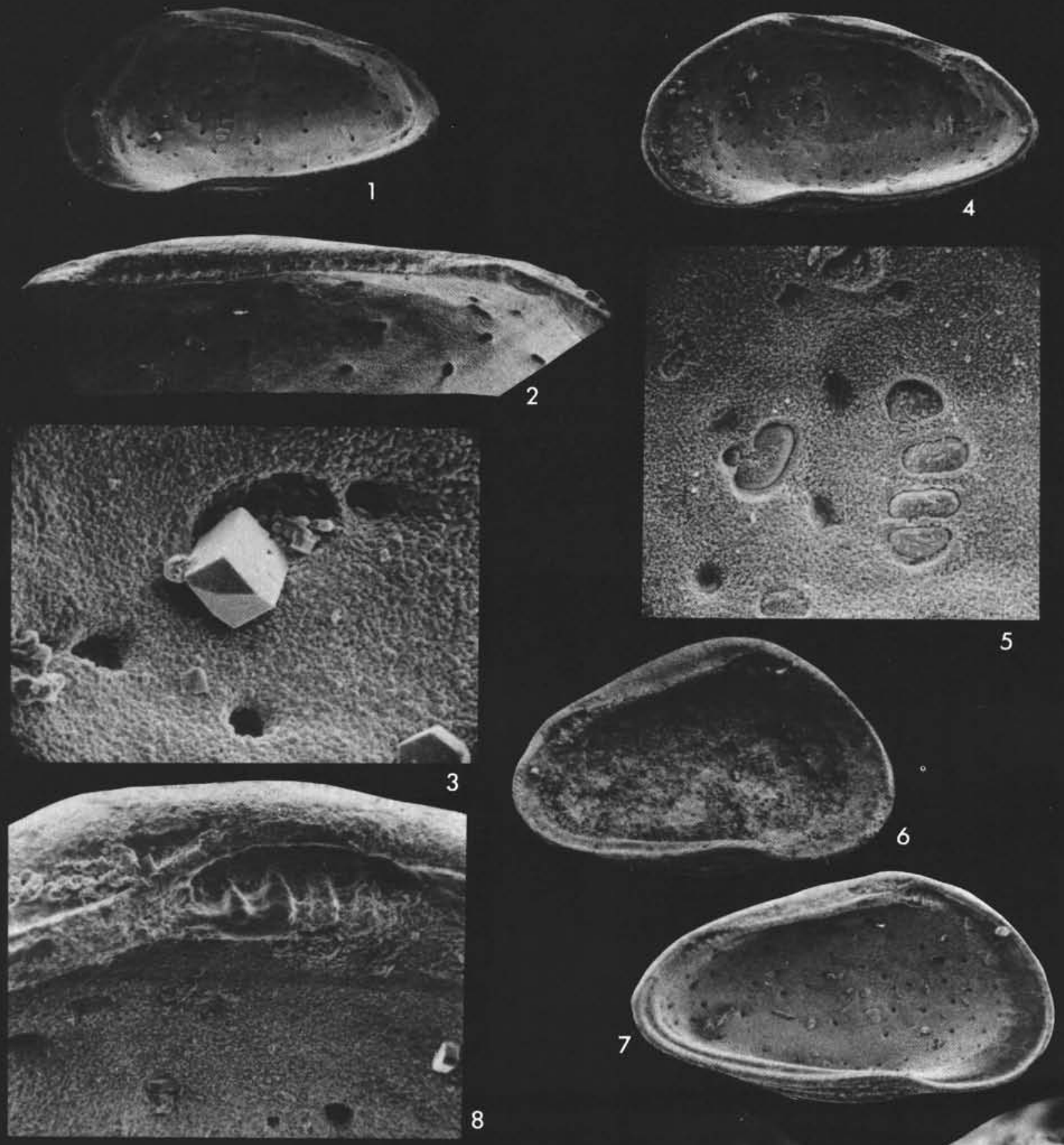

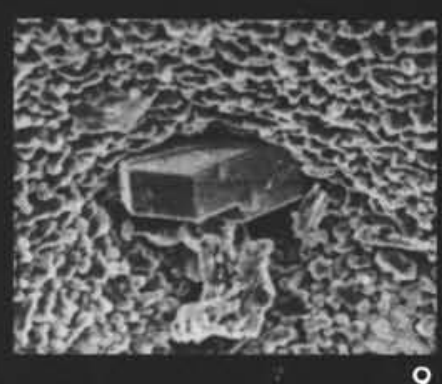

$$
9
$$

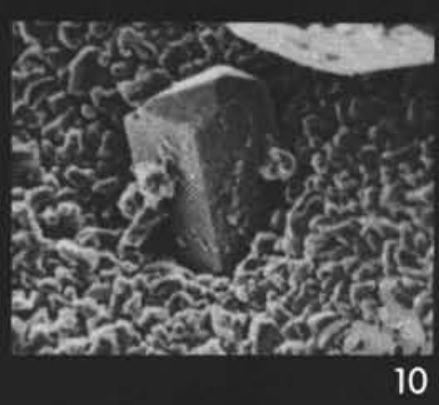

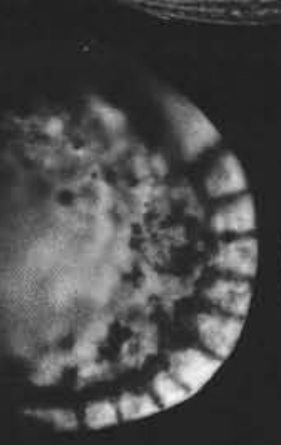

11

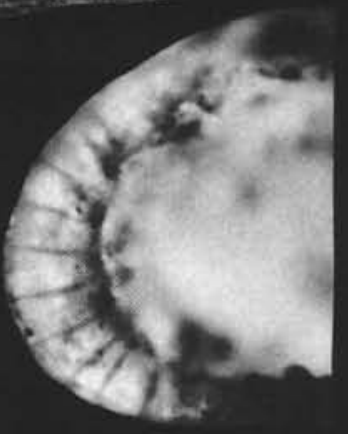

12 
PLATE 6

Magnifications: Figures 1, 3-6, 8: $\times 45$;

Figures 2, 10, 11: $\times 180$; Figure 7: $\times 900$;

Figure 9: $\times 95$.

Localities: Figures 1-4, 6, 7: Sample 260-9, CC;

Figure 5: Sample 260-10-2, 34-36 cm; Figures 8-11:

Sample 260-11, CC.

Figures 1-11 Indet. sp. A (possibly a Robsoniella).

1. Partially separated carapace, ref. $35 / 7 / 1$.

2. Same specimen, showing detail of imbrication of the two valves.

3. Left valve, ref. $35 / 7 / 3$.

4. Left valve, ref. $35 / 7 / 2$.

5. Right valve, ref. $37 / 6 / 2$.

6. Right valve, ref. $35 / 7 / 4$.

7. Same specimen, detail of surface, showing coccoliths tightly stuck to the surface.

8. Left valve, ref. $37 / 3 / 2$.

9. Same specimen, detail of hinge line.

10. Same specimen, posterior part of hinge line.

11. Same specimen, anterior part of hinge line. 
PLATE 6
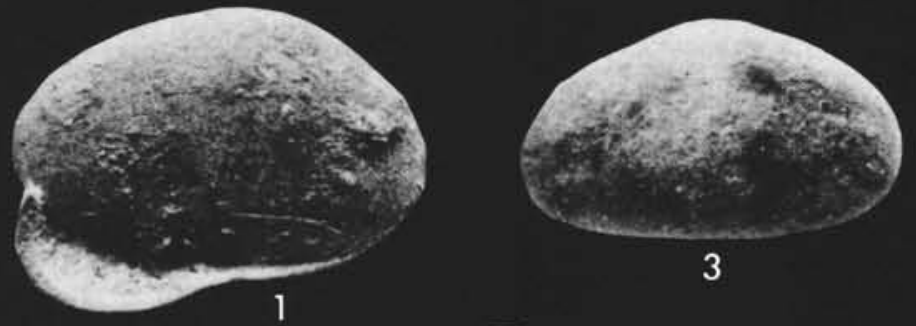

3

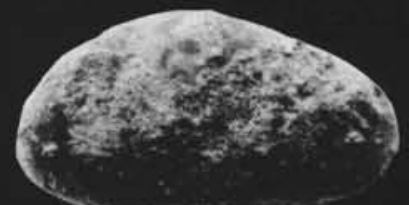

6
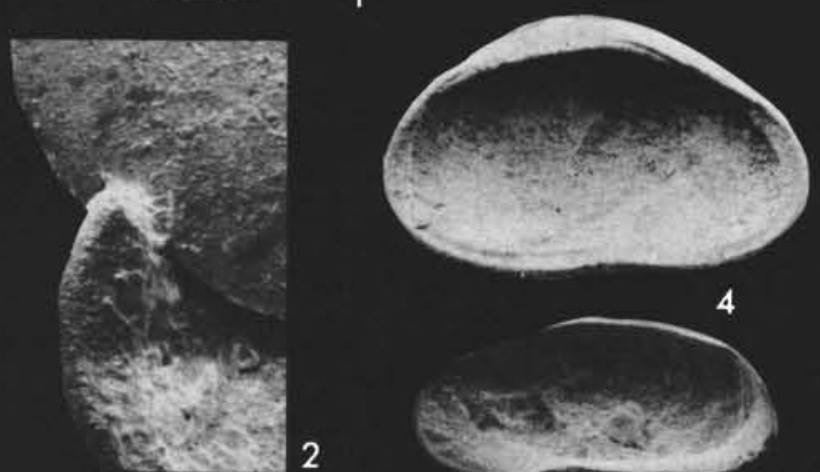

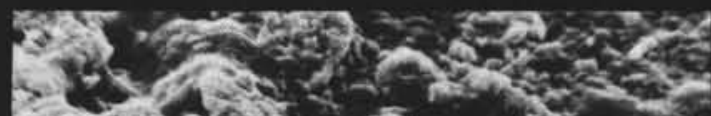
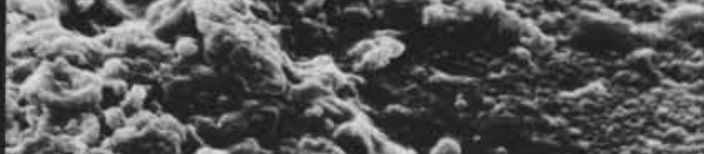

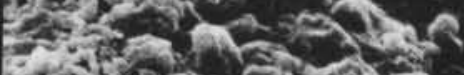

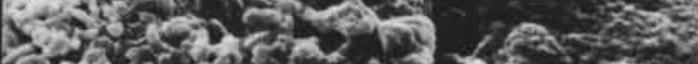

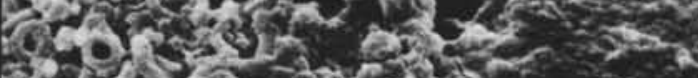
302 जो ते

2

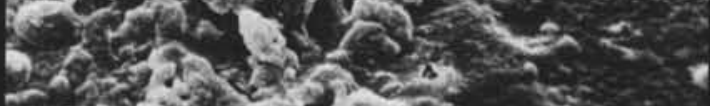

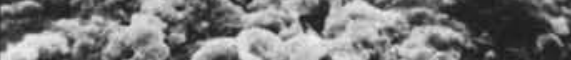
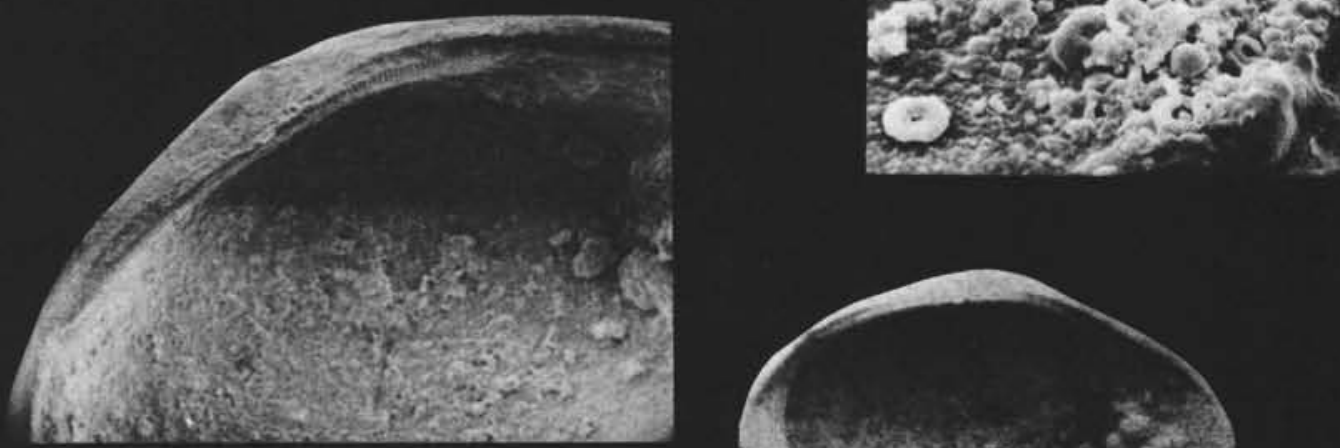

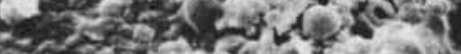

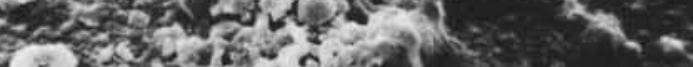

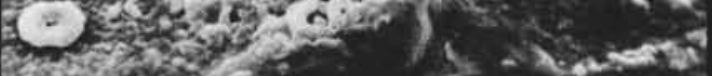

\section{9}
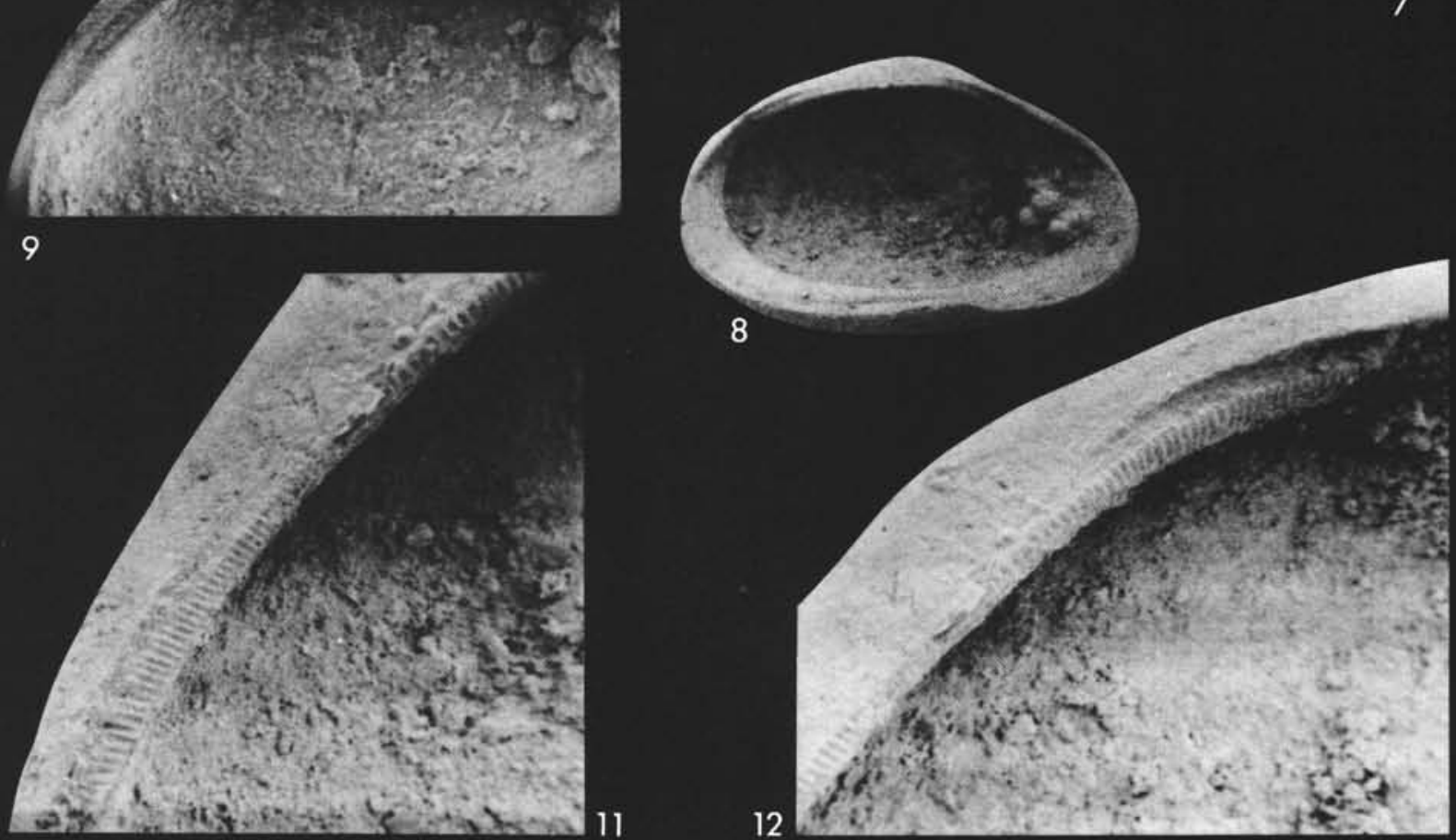


\section{PLATE 7}

Magnifications (all): $\times 180$ except Figure 7: $\times 90$. Localities: Figure 1: Sample 260-9, CC; Figure 2: Sample 260-10-1, 105-107 cm; Figure 3: Sample 263-26-5, 137-139 cm; Figure 4: Sample 263-29, CC; Figure 5: Sample 263-29, CC; Figures 6-12: Sample 261-1-1, 0-20 cm.

Figure I Indet. sp. B. Carapace, ref. 35/9/2.

Figure 2 Indet. sp. C. Left valve, ref. 36/1/1.

Figure 3, 4 Indet. sp. D.

3. Carapace, ref. $37 / 4 / 1$.

4. Carapace, ref. $37 / 4 / 2 \frac{1}{2}$.

Figure $5 \quad$ Indet. sp. E. Carapace, ref. 36/4/1.

Figure 6 Acrocythere? sp. A. Left valve, ref. 36/2/7.

Figures 7-12 Indeterminata

7. Right valve (Bythocypris ? Pontocyprella?), ref. $36 / 2 / 1$.

8. Left valve (Schuleridea ?), ref. 36/2/4.

9. Left valve, ref. $36 / 2 / 3$.

10. Left valve, ref. $36 / 2 / 2$.

11. Right valve (Metacytheropteron ?), ref. $36 / 2 / 1$.

12. Right valve, ref. $36 / 2 / 5$. 
PLATE 7
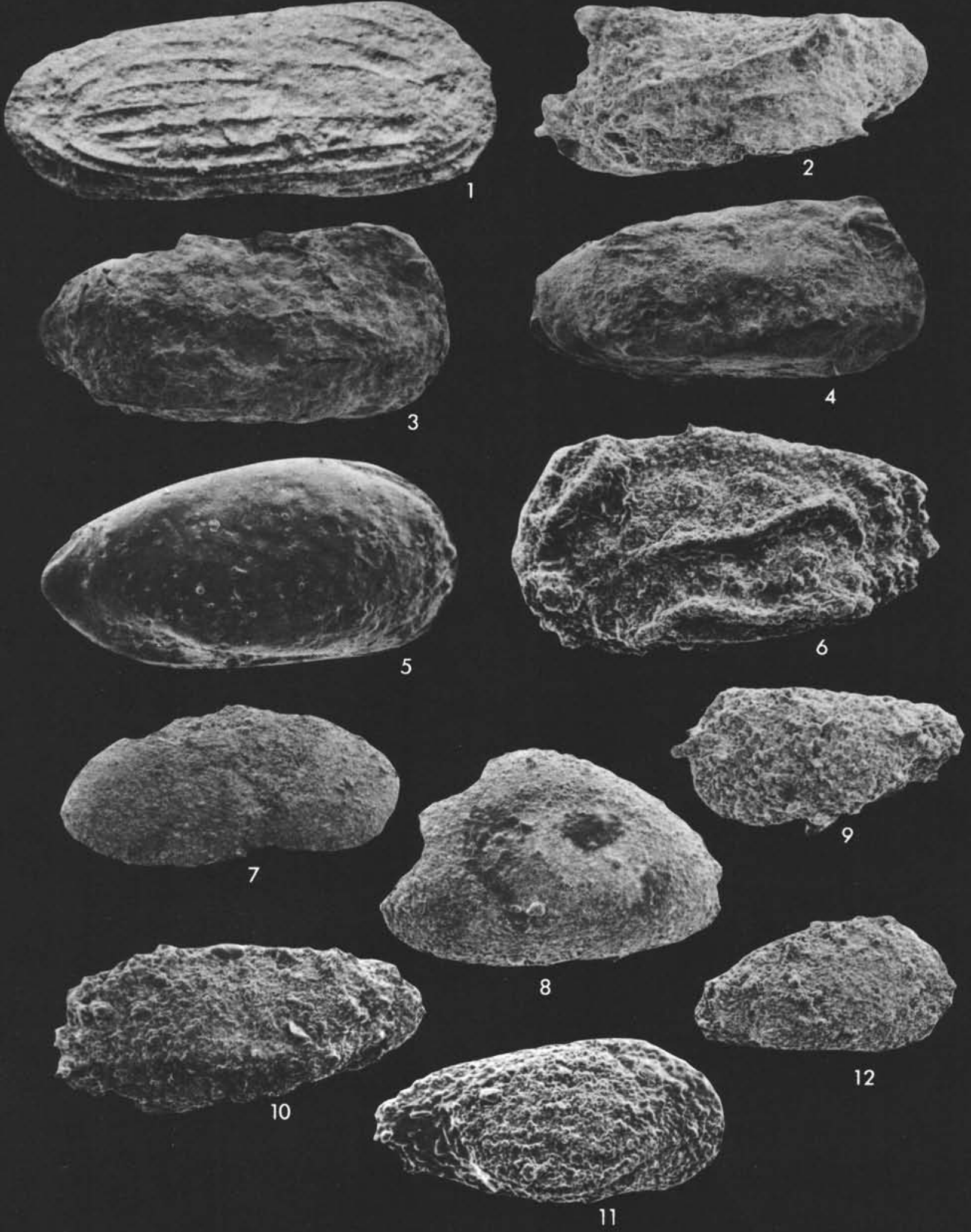